\title{
Multiple Infectious Agents and the Origins of Atherosclerotic Coronary Artery Disease
}

\author{
James S. Lawson* \\ School of Biotechnology and Biomolecular Sciences, University of New South Wales, Sydney, NSW, Australia
}

Although deaths due to atherosclerotic coronary artery disease (ACAD) have fallen dramatically during the past 50 years, ACAD remains as the leading cause of death in all continents, except Africa, where deaths due to infections are still dominant. Although food and nutrition have a proven role in atherosclerosis, the underlying causes of ACAD remain unknown. This is despite a century of intensive research dominated by investigations into the saturated fat hypothesis. In this review, it is hypothesized that the rise and fall in ACAD during the past 100 years is primarily due to the parallel rise and fall in the prevalence of coronary atheroma, the underlying disease. It is further hypothesized that infectious pathogens initiate atherosclerosis mainly during infancy and childhood. It is speculated that widespread use of antibiotics and vaccines against bacterial and viral infections

OPEN ACCESS

Edited by:

Jun-ichi Abe,

University of Texas MD Anderson

Cancer Center, USA

Reviewed by:

Masuko Ushio-Fukai,

University of Illinois at Chicago, USA

Xinchun Pi,

Baylor College of Medicine, USA

*Correspondence: James S. Lawson

james.lawson@unsw.edu.au

Specialty section:

This article was submitted to

Atherosclerosis and Vascular

Medicine, a section of the journal

Frontiers in Cardiovascular Medicine

Received: 30 March 2016

Accepted: 29 August 2016

Published: 12 September 2016

Citation:

Lawson JS (2016) Multiple

Infectious Agents and the

Origins of Atherosclerotic

Coronary Artery Disease.

Front. Cardiovasc. Med. 3:30. doi: 10.3389/fcvm.2016.00030 may be the reason for the dramatic fall in coronary atheroma and ACAD during the past 50 years. The relevant evidence and a working hypothesis are included in this review.

Keywords: atherosclerosis, coronary disease, infectious pathogens, diet and nutrition, coronary atheroma, trends

Chlamydia pneumoniae, cytomegalovirus, hepatitis C, Epstein Barr virus, human papilloma virus, human immunodeficiency virus, enterobacteriaceae, and other infectious pathogens may initiate atherosclerotic vascular diseases.

\section{HYPOTHESIS}

The main risk factors for atherosclerotic coronary artery disease (ACAD) are genetics, abnormal blood lipids, hypertension, diabetes, tobacco smoking, and glucose intolerance. In addition to these well-documented risk factors, it is hypothesized that (i) ACAD is initiated by multiple infectious pathogens, (ii) these pathogens have adverse influences on the endothelial lining and smooth muscle cells of blood vessels, which lead to inflammation of the vascular system, (iii) some pathogens influence lipid metabolism, (iv) several pathogens may live in the vascular system for decades and cause atheroma, (v) there is an influence of food on these pathogens and the formation of atheroma, and (vi) total food consumption has an additional independent influence on ACAD.

\section{BACKGROUND}

Atheroma or atherosclerosis is a chronic inflammatory disease of the arterial wall (1). Atherosclerosis in arterial walls is characterized by the invasion and accumulation of white blood cells, which transform into macrophages. Macrophages ingest lipids becoming "foam" cells. Concurrently, there is proliferation of vascular smooth muscle cells, resulting in the creation of fibrofatty plaques. These changes result in thickening of the walls of arteries. The early signs of atherosclerosis are fatty streaks lining the arteries, which years later, develop into plaques. These plaques may rupture and induce 


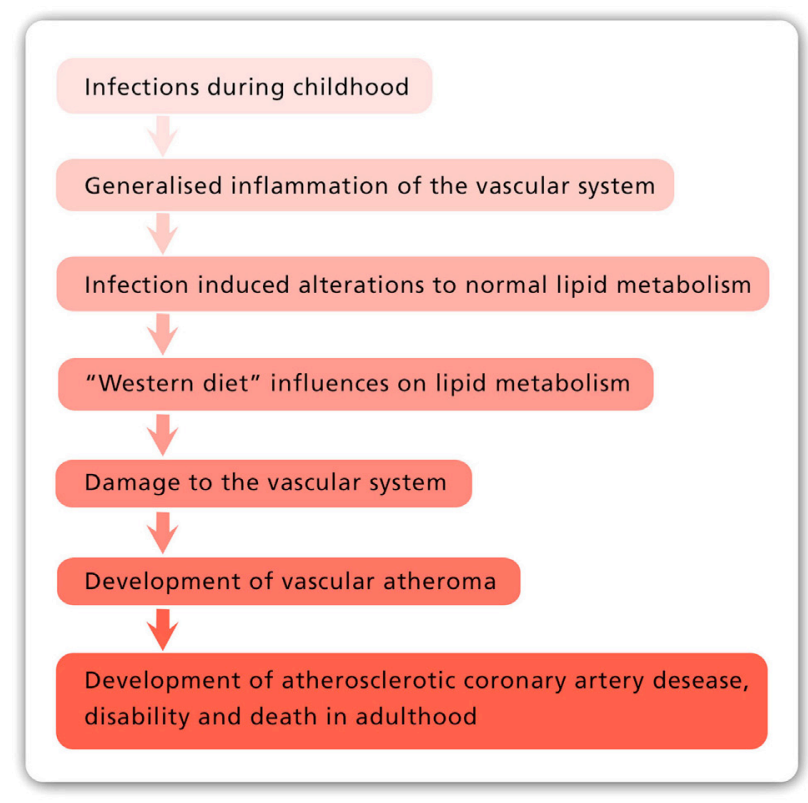

thrombus formation in the lumen of an artery, which may lead to thromboembolism or arterial occlusion with consequent coronary ischemia and death (1).

There is sound evidence that atherosclerosis is initiated in infancy and childhood and is associated with childhood infections that develop later age atheroma (2-5). Autopsy based data have shown that ACAD can begin in the perinatal period and early childhood and can be well established by the teenage years $(2,3,6,7)$. Several of these studies are based on retrospective observations of the same subjects over a 30-year period and indicate that there may be an over two times increased risk of cardiovascular disease in adulthood following a serious (sufficient to cause hospitalization) childhood infection $(4,5)$. The identification of specific pathogens was not made in these studies. Many Western children may have early and even advanced atheroma at ages $12-14$ years $(2,3,7,8)$. Autopsy-based studies of young US white and black subjects, killed between 1987 and 1994 because of accidental trauma or homicide, have demonstrated that over half of the right coronary artery of the youngest age group (15-19 years) had atheromatous lesions (8). This is similar to the coronary atheroma lesions observed in young (average age 22-27 years) German (1914) killed in World War I and US soldiers killed in the Korean (1951-1953), Vietnam (1965-1975), and the Afghanistan and Iraq wars (2001-2011) (9-12).

Advanced atheroma of a coronary artery in a 17 -year-old girl is shown in Figure 1.

\section{Trends in the Prevalence of Atherosclerosis and the Search for the Underlying Causes of Atherosclerosis}

The rise and fall in the number of deaths due to ACAD over the past 100 years in the US is typical of other Western countries including the United Kingdom, Germany, and Australia (14). Data from the US are of special value as they are available for over 100 years. As shown in Figure 2, deaths in the US due to ACAD

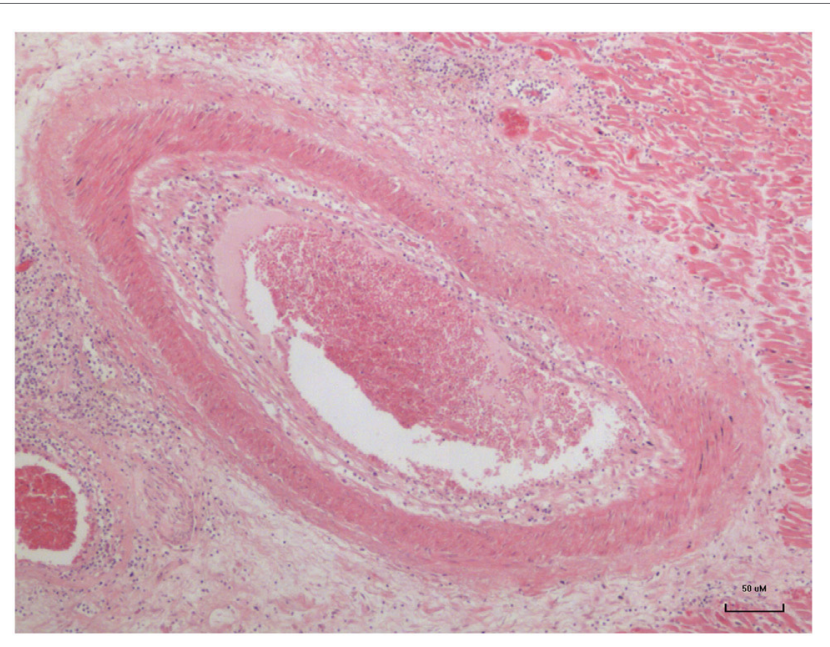

FIGURE 1 | Advanced atheroma in the coronary artery of a 17-year-old girl (13).

rose from approximately 140 per 100,000 population in 1900 to a peak of 355 in 1960 followed by a remarkable decline to 170 in 2010 (15). These data are based on variations of the diagnosis of heart disease and must be regarded as trends rather than precise figures. However, the historical data are broadly in line with more recent data based on specific diagnoses of coronary artery disease and age-adjusted annual death rates per 100,000 of the total US population (16). These later data indicated a 76\% decline during the past 50 years (16).

In addition to this pattern of deaths due to coronary artery disease, there has been an equally dramatic fall in the prevalence of atheroma of the coronary arteries. This is also shown in Figure 2. The data in Figure 2 are based on the direct observation of coronary arteries during autopsies conducted on soldiers killed in wars over a 100-year period. These autopsies clearly demonstrate coronary atheroma in physically fit young men (average age 22-27 years) from Germany (First World War 1915) and the US (Korea 1950-1953, Vietnam 1964-1975, Iraq and Afghanistan 2001-2011) (9-12). These data are shown in more detail in Table $\mathbf{1}$.

The data based on each war period are not strictly comparable due to different diagnostic criteria and autopsies conducted by different pathologists. Therefore, the validity of the data, based on autopsies of soldiers over a 100-year period, needs to be considered. First, the diagnosis of coronary atheroma by gross observation and light microscopy is not difficult and is reasonably consistent. Second, the prevalence of coronary atheroma based on autopsies in male soldiers in 1950-1953 was broadly similar to that observed in military pilots in 1980-1982 (17) and to those made on US civilians between 1950 and 1994 (18). Among the military pilots, Booze and Staggs observed a fall of severe coronary atherosclerosis from 5 to $2.5 \%$ between $1975-77$ and 1980-82 (17). Third, based on uniform autopsy techniques in studies conducted in New Orleans, the extent and prevalence of atherosclerotic lesions in the coronary arteries and aortas of deceased 25- to 44-year-old white men significantly decreased 


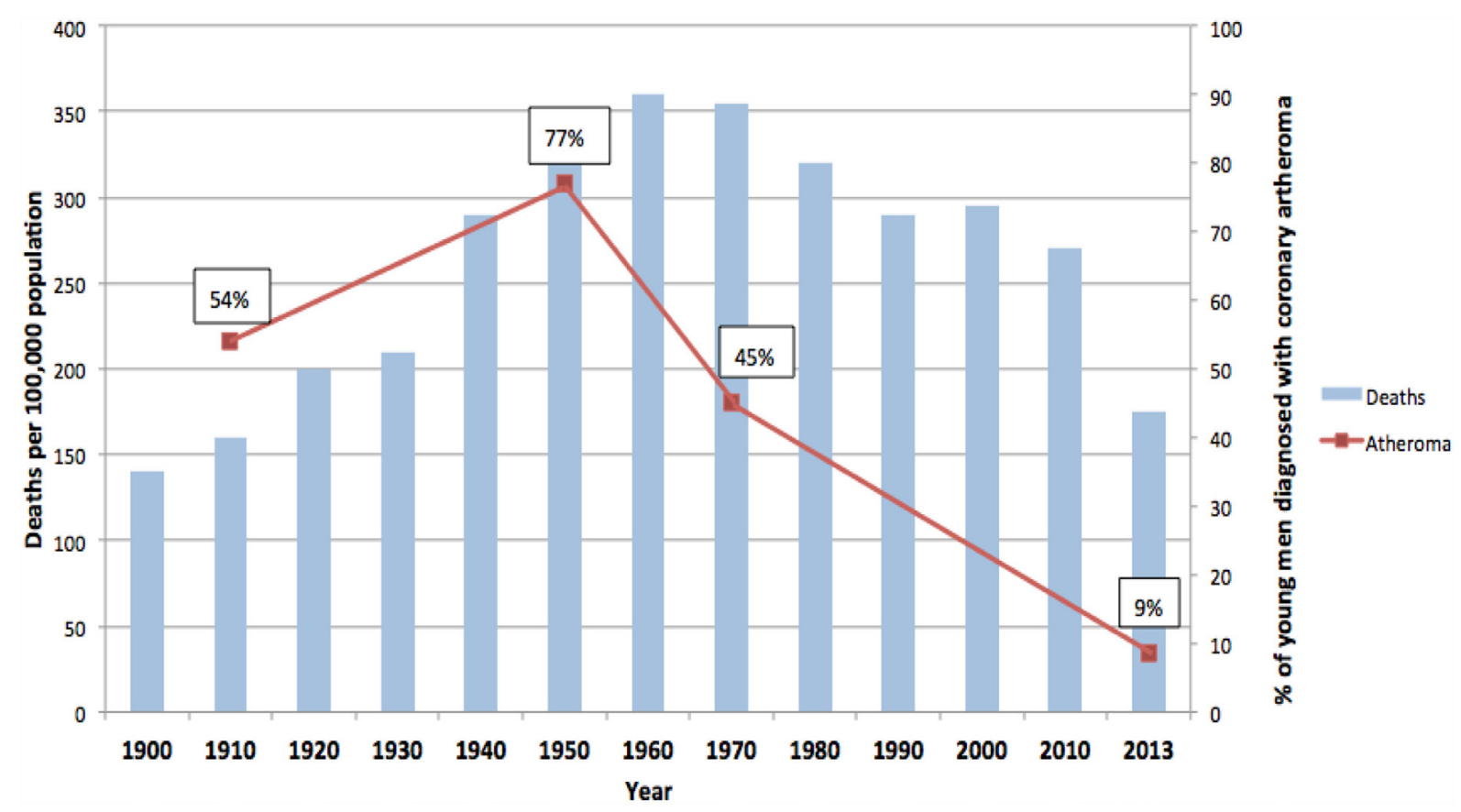

FIGURE 2 | Deaths due to coronary artery disease USA (blue columns). Coronary atheroma prevalence (red line). 100-year trends (9-12, 15).

TABLE 1 | Prevalence of atheromatous coronary artery disease in young Western soldiers (over 98\% males) killed in World War I, Korea, Vietnam, Iraq, and Afghanistan (9-12).

\begin{tabular}{|c|c|c|c|c|}
\hline $\begin{array}{l}\text { Age groups } \\
\text { deceased soldiers }\end{array}$ & $\begin{array}{l}1915 \text { World war I } n=171 \\
\text { (mostly German soldiers) (i) }\end{array}$ & $\begin{array}{l}\text { 1950-1953 Korea } n=300 \\
\text { (US soldiers) (ii) }\end{array}$ & $\begin{array}{l}\text { 1964-1975 Vietnam } n=105 \\
\text { (US soldiers) (iii) }\end{array}$ & $\begin{array}{l}\text { 2001-2011 Iraq and Afghanistan } \\
n=3,832 \text { (US soldiers) (iv) }\end{array}$ \\
\hline$<25$ years & $22 / 50$ (44\%) & na & na & 135/2,047 (7\%) \\
\hline 25-29 years & 23/47 (49\%) & na & na & 103/931 (11\%) \\
\hline 30-39 years & 21/35 (60\%) & na & na & 154/697 (22\%) \\
\hline $40+$ years & $26 / 39$ (67\%) & na & na & $72 / 157$ (46\%) \\
\hline Average age & 29 years & 22 years & 22 years & 26 years \\
\hline $\begin{array}{l}\text { Atheroma all } \\
\text { ages (\%) }\end{array}$ & $92 / 171$ (54\%) & $232 / 300(77 \%)$ & 47/105 (45\%) & $\begin{array}{l}464 / 3,832(12 \% \text { aorta + coronary; } \\
9 \% \text { coronary })\end{array}$ \\
\hline
\end{tabular}

The age specific data, based on autopsies of soldiers killed in World War I and in the Afghanistan and Iraq wars, are of particular interest because of the clear demonstration that the prevalence of coronary atheroma increases markedly with age.

na, not available.

between 1960-64 and 1969-78 (19). These declines were not observed among same aged black men. Fourth, and also based on a uniform system of autopsy techniques, the prevalence of coronary atheroma among men and women below the age of 60 years decreased from 38 to $27 \%$ during the period 1979-1994 in Olmsted County, MN, USA (20). There was a further decline in coronary atheroma of approximately $20 \%$ among the same population between 1995 and 2012 (15). The decline in prevalence of coronary atheroma in Olmsted County was greater among young as compared to older citizens. The rate of decline in coronary atheroma has slowed in recent years (15). Because these data are based on a wide range of age groups, they are not directly comparable to the age-specific data based on US soldiers. However, the decline in coronary atheroma demonstrated by the New Orleans and Olmsted autopsy-based data parallels and adds validity to the US soldier-based data $(15,19)$. Overall, the data from different sources are consistent, particularly with respect to the decline in prevalence of coronary atheroma among young men. It is concluded that the decline in coronary atheroma is real and not due to different methods of assessing autopsy findings.

The rise and fall in the prevalence of coronary atheroma closely parallels the prevalence of deaths due to coronary artery disease in the US during the same periods of time (see Figure 2) (15). This decline in deaths due to ACAD is in part due to a reduction in risk factors and improvements in surgical and medical treatments. However, as hypothesized in this review, it is likely that the decline in the underlying disease, namely atherosclerosis, has been the dominant factor. The fall in deaths due to coronary artery disease by approximately two-thirds during the past 50 years has occurred in all Western countries (21). The epidemiological trends of deaths due to coronary artery disease are different in Eastern European, South American, and Asian populations (21). The pattern of a dramatic rise and fall in deaths is typical of an infectious-based disease. 
It should be noted that (i) different methodologies and assessments by pathologists over a 100-year period apply to the atheroma autopsy-based studies (red line) and (ii) different criteria apply to the deaths attributed to coronary artery disease (blue columns). Accordingly, these data indicate trends and not precise measurements.

\section{Infectious Pathogens}

The classic risk factors for atherosclerosis are well established $(22,23)$. These risk factors include excess body weight, dyslipidemia, hypertension, tobacco smoking, genetics, diabetes, and glucose intolerance. An important feature of atherosclerosis is the marked increase in prevalence associated with increased age. This indicates an ongoing chronic process.

In addition to these risk factors is the likely role of infectious pathogens. The first experimental evidence that infectious pathogens could cause atherosclerosis in blood vessels was developed by Fabricant et al. in 1978 (24). They demonstrated that Marek's herpes virus could cause atherosclerosis in chickens. Infection with this herpes virus was required to induce atherosclerosis whether or not the chickens were fed a high or low cholesterol diet. They also demonstrated that infections with these herpes viruses altered intracellular lipid metabolism (25). Importantly, this infectious phenomenon could be prevented by vaccination (26). These observations of atherosclerosis in chickens closely resemble atherosclerosis in humans and are a key to the hypothesis that infectious pathogens may have a causal role in vascular atherosclerosis in humans (26).

A number of herpes viruses have been identified in atherosclerotic coronary arteries and normal vascular structures in humans. These herpes viruses include Epstein-Barr virus (EBV) (human herpes virus 4), Cytomegalovirus (CMV) (human herpes virus 5), and herpes simplex virus (HSV) (human herpes virus 1 and 2) (13, 27, 28). Infections with EBV and other herpes viruses are associated with atherogenic lipid changes (29-32).

Multiple additional pathogens in both normal and atherosclerotic blood vessels have been identified $(33,34)$. The pathogens identified in normal blood vessels by a species-specific approach include Chlamydia pneumoniae (Cp), Helicobacter pylori, Mycoplasma pneumoniae, CMV, hepatitis C, HSV, EBV, human papilloma virus (HPV), and human immunodeficiency virus (HIV) $(13,27,35,36)$. There is an extensive list of additional pathogens, which have been identified in atherosclerotic plaques by massive computerized gene sequencing (34). These include the pathogen families, such as porphyromonadaceae, bacteroidaceae, micrococcaceae, streptococcaceae plus viruses such as EBV and HPVs. The importance of these observations is (i) they demonstrate that the long held view that blood vessels were sterile is incorrect and (ii) that pathogens in blood vessels are not necessarily parasites, which infect atheromatous plaques.

\section{Epidemiological Evidence for a Role of Infectious Pathogens in Atherosclerosis}

There is epidemiological evidence, which is supportive of a role by several specific pathogens in atherosclerosis.

\section{Periodontal Porphyromonas gingivalis}

Pathogens associated with periodontal infections have been extensively studied. A higher periodontal pathogen load with Porphyromonas gingivalis has been identified in patients with atherosclerotic vascular disease as compared to controls $(33,37)$.

\section{Human Papilloma Virus}

Women with HPV genital infections have up to threefold increased risk of atherosclerotic vascular disease (38), and high risk for cancer HPVs have been identified in atheromatous plaques and in coronary artery smooth muscle cells (13). There is experimental evidence that human aortic smooth muscle cells proliferate when exposed to HPVs (39).

\section{Chlamydia pneumoniae}

There are many studies, which confirm the presence of $\mathrm{Cp}$ in atheroma plaques (40). In a large study of Japanese men and women, high levels of serum antibodies to Cp were associated with a doubling of the prevalence of ACAD (41). These findings, suggesting a role for $\mathrm{Cp}$ in atherosclerosis, have been supported by recent experiments, which show that a single infection of $\mathrm{Cp}$ is sufficient to exacerbate atherosclerosis in mice (42).

\section{Enterobacteriaceae}

There is a possible link between the identification of enterobacteriaceae in vascular atherosclerotic lesions and serious childhood infections with later adult $\operatorname{ACAD}(4,5,43)$. This is because many serious childhood infections are caused by enterobacteriaceae in the renal tract.

\section{Infections and Chronicity}

It is possible that chronic infections may have a role in the marked increase in the prevalence of ACAD between the ages of 20 and 40 years. This increase in ACAD associated with age was clearly demonstrated by the study of atherosclerosis in US soldiers killed in the Iraq and Afghanistan wars (12). While the reasons are not known, $\mathrm{Cp}$ has the capacity to cause inflammation over decades of time. Similarly, high risk for cancer HPVs may cause persistent inflammation and a tripling of the risk of ACAD in women $(13,38)$. CMV and EBV also have the capacity to persist over decades $(35,44)$.

\section{Microbiota}

Microbiota refers to the hundreds of different bacteria and viruses that are located throughout the body. The largest and most diverse microbiota location is the gut. While the evidence is not definitive that the gut or other microbiota influence the development of atherosclerosis, there is substantial evidence in support of this notion $(45,46)$. There are different microbiotas in different locations, including the genital tract, blood, and even atherosclerotic plaques (46). On the other hand, atherosclerotic plaques, the gut, and periodontal locations can have similar microbiota in the same patients (46). This microbiota can be dominated by Escherichia coli (46). This suggests that there may be similar biological influences in these very different locations. The composition of the gut microbiota is influenced by diet and infectious pathogens and also by antibiotics $(47,48)$. 
Of particular interest is the relationship between viruses and bacteria in the gut (49). Several viruses, including noroviruses (the cause of $85 \%$ of gastroenteritis cases), mouse mammary tumor virus (the cause of breast cancer in mice and other mammals probably including humans), poliomyelitis virus, reovirus (the cause of respiratory and gastrointestinal infections), each require the co-location of bacteria in the gut to allow these viruses to enter cells (49). The special interest is because in experiments in which these viruses were exposed to antibiotics that inhibited gut bacteria, these viruses could not enter the target cells (49). This is relevant to the hypothesis that antibiotics may be one reason for the decline in the prevalence of atherosclerosis.

\section{Food}

For over 50 years, food consumption patterns have been the dominant causal hypothesis for vascular atheroma. Overall, the epidemiological studies on humans and the experimental studies on animals offer consistent observations that food consumption patterns are associated with coronary artery disease. The caution expressed decades ago by Marmot and Syme (50) and Truett et al. (51), that ACAD had more complicated origins than simply diet, was especially farsighted because at the time of their writing, it was not known that pathogenic infections could cause changes in lipid metabolism.

There has been a dominance of the saturated fat and coronary heart disease hypothesis. This is mainly due to the studies and promotion by Keys and his colleagues (52). This hypothesis was based on Keys' famous Seven Country Study, which demonstrated that coronary heart disease was most common in Western dairy and red-meat eating countries and was associated with high blood lipid levels (52). During the same period, prospective studies were conducted in the town of Framingham in the US (53). These studies showed that high blood pressure, high blood cholesterol levels, obesity, and tobacco smoking were associated with increased risk of coronary artery disease (53). Despite the clear statements from the Framingham research group that evidence was not available upon which to base action, for the next 50 years, the views of the Ancel Keys research group became the basis of formal dietary guidelines in most Western countries. These guidelines included dogmatic advice for citizens of Western countries to reduce consumption of saturated fats, including most dairy foods. The assumption by the Ancel Keys group that a reduction in dietary saturated fats on a population basis would lead to a reduction in serum cholesterol is flawed. This is because cholesterol synthesis is regulated by a system of enzymes, which maintain the body's cholesterol levels within a narrow range. When saturated fat intake increases, endogenous cholesterol production decreases. When the intake of saturated fat is decreased, endogenous production increases to maintain serum cholesterol levels relatively constant (54). It should be noted that while it is possible to lower serum cholesterol in individuals by diet, the required diets are so severe that they are not sustainable.

The findings of these early studies, which demonstrated the influence of food consumption patterns on atherosclerosis, have been repeatedly confirmed. However, many studies sought to emphasize a potential harmful role of saturated fats. This emphasis has been shown to be misleading, and there is now a substantial body of evidence available that demonstrates the limited role of saturated fats in atherosclerosis (55-58). The recent Cochrane Collaboration (59) review of the evidence relevant to this issue concluded "...cutting down on saturated fat led to a $17 \%$ reduction in the risk of cardiovascular disease (including heart disease and strokes) but no effect on the risk of dying."

On the other hand, there is compelling epidemiological evidence that total food consumption, as distinct from specific components of food, is associated with the prevalence of ACAD. In both low and high risk for ACAD countries, an increase in the body mass index is positively associated with increased incidence of ACAD (22). Of particular interest is the recent 40 -year prospective nationwide study of approximately 2.5 million Israeli adolescents, which demonstrated that overweight Israeli teenagers were almost twice as likely and obese teenagers were up to five times as likely to have a fatal heart attack or stroke during middle age (60).

For over five decades, there has been a consistent association between total per capita food consumption and ACAD in both low and high risk for ACAD countries. This is shown in Table 2. In 1961, the daily apparent consumption of calories in South Korea was 2,141 as compared to over 3,000 in US, which positively correlates to the 1993 death rates due to coronary artery disease of 13.5 in South Korea as compared to 107.5 per 100,000 total population in the US $(61,62)$. As also shown in Table 2, these trends have persisted to the present time with a doubling of deaths associated with coronary artery disease in Korea, associated with a marked increase in food consumption. By way of contrast, death rates due to coronary artery disease have halved in Australia, the United Kingdom, and the US, despite only modest increases in food consumption.

The prevalence of ACAD based on autopsy findings among Japanese living in Hawaii and California is up to 3.5 times more frequent and more severe than Japanese living in Japan $(63,64)$. Serum cholesterol was significantly higher in the Japanese Hawaiians and Californians. However, as Marmot observed, when Japanese men ate equivalent diets in the three places, the Japanese Americans still had higher serum cholesterols than the Japanese in Japan (50). The implication being that serum cholesterol is due to factors other than fat consumption.

TABLE 2 | Asian (South Korea, Japan) and Western (Australia, United Kingdom, US) apparent daily per capita food consumption in kilocalories 1954/1961 and 2006/2008 and age-adjusted death rates per 100,000 population due to coronary artery disease 1993 and $2014(61,62)$.

\begin{tabular}{lcccc}
\hline & $\begin{array}{c}\text { Daily } \\
\text { kilocalories } \\
\text { 1954/1961 }\end{array}$ & $\begin{array}{c}\text { Daily } \\
\text { kilocalories } \\
\text { 2006/2008 }\end{array}$ & $\begin{array}{c}\text { Deaths } \\
\text { coronary artery } \\
\text { disease 1993 }\end{array}$ & $\begin{array}{c}\text { Deaths } \\
\text { coronary artery } \\
\text { disease 2014 }\end{array}$ \\
\hline $\begin{array}{l}\text { South } \\
\text { Korea }\end{array}$ & 2,141 & 3,040 & 13.5 & 26.4 \\
Japan & 2,070 & 2,800 & 21.5 & 30.4 \\
$\begin{array}{l}\text { Australia } \\
\text { United }\end{array}$ & 3,230 & 3,220 & 112.6 & 54.9 \\
Kingdom & 2,570 & 3,450 & 118.9 & 60.1 \\
US & 3,150 & 3,800 & 107.5 & 78.0
\end{tabular}


The patterns of food consumption in the US offer important support for the view that the components of diets, such as saturated fats and cholesterol, have little association with the prevalence of atheromatous coronary artery disease. These patterns are shown in Table S1 in Supplementary Material. In the US, during the past 50 years, food energy has increased by $25 \%$, protein consumption by $32 \%$, and total fats by $38 \%$. Consumption of cholesterol and added sugars has been stable. The overall patterns of food consumption shown in Table S1 in Supplementary Material parallel the high prevalence of obesity in the US. During this same period, the consumption of saturated fats increased by approximately $10 \%$ (Table S1 in Supplementary Material). These US food consumption trends are opposite to what would have been expected if the saturated fat and atheroma hypothesis had been true.

\section{MECHANISMS}

\section{Infectious Pathogens}

There are several excellent reviews of the role of infectious pathogens and atherosclerosis by Epstein et al., Campbell and Rosenfeld, Feingold and Grunfeld, and Clifford and Hoffman (65-68). These reviews, plus additional material, have been used to explore the underlying mechanisms of infections and atherosclerosis as outlined below.

Multiple infectious pathogens contribute to acute and chronic inflammation of the vascular system (66). Although the evidence is not entirely consistent, infections of vascular wall cells lead to inflammation and atherosclerosis. The specific mechanisms differ between various pathogens. Both CMV and Cp appear to induce proliferation of vascular smooth muscle cells by inhibition of the tumor suppression gene p53 $(69,70)$. CMV, Cp, and HSV can each have an atherogenic effect, including smooth muscle proliferation, increased expression of cytokines, chemokines, and an increased uptake of low density lipoprotein (71).

There also appear to be infectious pathogen-associated autoimmune mechanisms associated with atherosclerosis. These mechanisms are complex and involve the increased expression of heat shock proteins (HSPs) in response to stress, such as infections. In some circumstances, these proteins may appear as "foreign" and engender an autoimmune response. Many studies support the validity of this mechanism, including the encoding by all bacteria of HSPs (65). In addition, serum antibodies to HSPs are associated with carotid artery thickening, and serum antibodies to HSPs of E. coli and Cp are cytotoxic to vascular endothelial cells (65). It is also possible that viruses can evoke an HSP autoimmune response (64). An additional immune-based mechanism by which infectious pathogens may contribute to atherosclerosis is via toll-like receptors (TLRs). Pathogens can increase expression of TLRs and engender a chronic inflammatory response (65).

Infections and inflammation can have complex influences on lipids and lipoproteins (67). The most common influences are decreases in serum high density lipids and increases in triglycerides. The greater the severity of inflammation, the greater the abnormalities in lipids and inflammation. The underlying mechanisms are not clear.
Infections leading to vascular inflammation appear to have the capacity to influence risk factors associated with atherosclerosis.

\section{Infections and Diet}

There may be a connection between food consumption patterns, infection, and atherosclerosis. However, the evidence is very limited. Studies based on experimental animals suggest that the influence of infectious pathogens may differ according to the specific pathogen, the experimental animal, and type and quantity of food. Fabricant et al. demonstrated that Marek's herpes virus leads to atherosclerosis in both hypercholesterolemic and normocholesterolemic chickens (24). Similarly, P. gingivalis bacteremia has been shown to induce coronary and aortic atherosclerosis in both normocholesterolemic and hypercholesterolemic pigs (72). Turkay et al. demonstrated that in experimental rats, a combination of a high cholesterol diet and infection with Pseudomonas aeruginosa led to significantly greater arterial wall thickness than either infection or cholesterol diet administered alone (73). There are several experimental animal-based studies, which suggest that $\mathrm{Cp}$ is a risk factor for atherosclerosis in conjunction with hyperlipidemia (66).

There is limited relevant evidence in humans. Amazon forage horticultural people have high loads of infection, but low adiposity and virtually no arterial degeneration and $\operatorname{ACAD}(74,75)$. These observations suggest that infections alone may not cause atheroma in humans, and that "excess" food and nutrition plus infectious pathogens are also required. A precise definition of "excess" nutrition is not possible, but the average daily consumption of food in Western populations is over twice that of Amazon villagers (75).

\section{Infectious Pathogens, Inflammation, and Lipid Metabolism}

Because of the important role of lipids in vascular atherosclerosis, the role of specific infectious pathogens in the disruption and influence on lipid metabolism is relevant to the search for the underlying causes of atheroma (67). In Table 3, potential pathogens are listed together with their known influences on human and animal lipid metabolism.

TABLE 3 | Influence of pathogens on human and experimental animal lipid metabolism.

\begin{tabular}{lcc}
\hline Pathogen & $\begin{array}{c}\text { Abnormal lipid } \\
\text { metabolism } \\
\text { humans }\end{array}$ & $\begin{array}{c}\text { Abnormal lipid } \\
\text { metabolism } \\
\text { experimental animals }\end{array}$ \\
\hline Chlamydia pneumonaie & + & + \\
Porphyromonas gingivalis & + & na \\
Epstein-Barr virus & + & na \\
Hepatitis C & + & na \\
Cytomegalovirus & + & na \\
Helicobacter pylori & + & na \\
Human papilloma virus & + & na \\
Enterobacter coli & na & na \\
Marek's herpes virus & na & + \\
Herpes viruses & + & na \\
Human immunodeficiency virus & + & na \\
\hline
\end{tabular}

+, disruption or abnormal lipid metabolism, na, data not available. 


\section{Human Immunodeficiency Virus}

The influence of HIV to increase the risk of ACAD has been studied in detail. Chronic HIV infections are associated with abnormal lipid metabolism, which in turn is associated with increased $\operatorname{ACAD}(36,76)$.

\section{Chlamydia pneumonaie}

Chlamydia pneumonaie disrupts lipid metabolism in human umbilical vein endothelial cells and is associated with increased levels of total cholesterol in these cells (77). Cp-infected carotid artery macrophage foam cells contain abnormally high low density lipoproteins (78). Cp infections trigger the formation of lipid-laden foamy macrophages, as seen in atheromatous plaques (79). Cp-infected mice show significantly increased serum cholesterol and triglyceride levels compared to controls (80). Cp infections accelerate the development of atherosclerotic lesions in experimental mice fed with high-fat diets (81).

\section{Porphyromonas gingivalis}

Chronic oral infection with $P$. gingivalis accelerates atheroma formation by altering lipid metabolism (82). In addition, P. gingivalis increases lipid accumulation in foam cells (83).

\section{Epstein-Barr Virus}

Acute infection with EBV is associated with atherogenic lipid changes (30). EBV may also be involved in the inflammatory and autoimmune processes associated with atherosclerosis (84).

Hepatitis C alters host cell lipid metabolism (85).

Human CMV infections influence host cell sphingolipids and lipid metabolism $(86,87)$.

Helicobacter pylori influences serum lipids and appears to be associated with ACAD (88).

Herpes viruses influence arterial accumulation of cholesterol (29).

Human papilloma virus influences intracellular lipids (89).

Human immunodeficiency virus influences lipid metabolism and increases cardiovascular disease (90).

\section{REASONS FOR THE DRAMATIC DECLINE IN ATHEROSCLEROSIS AND THE FALL IN DEATHS DUE TO ATHEROSCLEROTIC CORONARY ARTERY DISEASE}

Determining the etiology of atherosclerosis is a complex task. Therefore, it is helpful to consider Karl Popper's concept of falsifiability or refutability of the hypotheses outlined in this review (91). These hypotheses will be nullified or falsified if they are shown to be invalid or false.

The decline in the prevalence of deaths due to ACAD during the past 50 years is extraordinary. A range of reasons for this dramatic decline have been offered (92). These include reductions in total serum cholesterol (24\%), tobacco smoking (12\%), blood pressure (20\%), and physical activity (5\%) plus treatments associated with revascularization (15\%), heart failure (9\%), and other therapies (12\%) (92). These explanations are well documented and appear to be valid. Importantly, none of these risk factors are relevant in infants, children, and young adults, among some of whom atheroma can be well established before the age of 22 years $(12,17,18)$. There must be additional explanations.

\section{Food}

While total excess energy consumption is associated with the formation of vascular atheroma, there is limited evidence to support the hypothesis that saturated or other dietary components are major contributors. The substantial increases in consumption by US citizens during the past 50 years, of all types of fats, proteins, and to some extent sugars, is the opposite of what would be expected with such a dramatic decline in vascular atheroma. This is in accord with Popper's concept of falsification.

\section{Tobacco}

There has been a substantial decline in tobacco smoking by US citizens during the past 50 years. Forty-two percent of US adults smoked tobacco in 1965, and this had fallen to 19\% in 2011 (93). It is likely that this has contributed to the decline in deaths due to coronary artery disease due to atherosclerosis, thrombosis, and coronary occlusion (94). However, this decline in tobacco smoking is unlikely to be a major factor in the substantial decline in atheroma in young soldiers (because of their extremely young average age) (12). Again, this is in accord with Popper's concept of falsification.

\section{Hypertension}

There is strong evidence that population-wide control of hypertension has resulted in a decline in deaths due to coronary artery disease (92). High blood pressure was associated with coronary atheroma in $43 \%$ of the US soldiers (although the numbers of soldiers with hypertension was small and unlikely to be present in the young soldiers and is again in accord with Popper's concept of falsification) (12). The prevalence of hypertension among US adults has fallen and then risen during the past 50 years (95). It is arguable that the control of hypertension has contributed to the decline in atheroma, but given the rise in the prevalence of hypertension in the US over the past 30 years, this is doubtful.

\section{Statins}

Statins have been widely available for the past 25 years. Statins can lower blood lipids by up to $50 \%$ and significantly reduce atherosclerotic plaques and have been shown to significantly reduce ACAD (96). The use of statins has illustrated the important associations between blood lipids and cardiovascular disease (96). However, the introduction of statins is relatively recent and well after the decline in coronary atheroma and ACAD. Importantly, statins are not prescribed for young adults and cannot have had a role in the reduction of coronary atheroma in this age group. Again, this is in accord with Popper's concept of falsification.

\section{Antibiotics and Vaccines}

Antibiotics and viral vaccines against a range of infectious diseases began to be used on a population-wide basis in the post World War II years. There is no direct evidence that antibiotics and viral vaccines have had an influence on atherosclerosis in humans, but it a plausible explanation as both have been shown to 
reduce atheroma in experimental animals $(26,97,98)$. A majority of children have been exposed to antibiotics following their widespread use since the 1950s. Many types of bacteria that have been identified in human blood vessels are sensitive to antibiotics, although bacteria, such as $\mathrm{Cp}$, are less sensitive but can be controlled by broad spectrum antibiotics.

There is a major impact on the commensural gut bacteria (the gut microbiota) by broad spectrum antibiotics $(99,100)$. Different antibiotics have different influences on specific components of the gut microbiota (99). The influence of antibiotics is well illustrated by the impact of maternal intrapartum antibiotics on gut microbiota, which persist during the first year of life (48). In experimental animals, antibiotics have been shown to alter bacterial composition and short-chain fatty acids in the cecum (100). Experiments on mice have demonstrated that antibiotics change the gut microbiota, which in turn lead to improvements in glucose tolerance, reduced plasma lipopolysaccharides, and altered hepatic and intestinal genes involved in inflammation (98). While the evidence is very limited, it is possible that antibiotics have an influence on gut microbiota, which in turn may have an influence on blood lipids and consequently on atherosclerosis.

It is also possible that vaccines against viral infections may prevent atheromatous processes. This hypothesis is based on the use of vaccines against Marek's herpes virus, which was shown to prevent herpes-induced atheroma in chickens by Fabricant and Fabricant (26).

As outlined above, several viruses, including noroviruses, mouse mammary tumor virus, poliomyelitis virus, and reovirus, each require the co-location of bacteria in the gut to allow these viruses to enter cells (49). There is experimental evidence that when these viruses were exposed to antibiotics that inhibited gut bacteria, these viruses could not enter the target cells (49). This is relevant to the hypothesis that antibiotics and vaccines may independently be the reasons for the decline in the prevalence of atherosclerosis.

\section{CONCLUSION}

There has been a substantial ( $70 \%$ among young people) decline in atherosclerosis of the coronary arteries during the past 50 years. There has been an equivalent decline in deaths due to ACAD in Western countries. Despite these declines, ACAD remains as the most common cause of death in all continents except Africa. The reasons for these declines are not clear. A plausible, but unproven,

\section{REFERENCES}

1. Libby P. Inflammation in atherosclerosis. Nature (2002) 420:868-74. doi:10.1038/nature01323

2. Stary HC. Lipid and macrophage accumulations in arteries of children and the development of atherosclerosis. Am JClin Nutr (2000) $72(5$ Suppl): 1297S-306S.

3. Milei J, Ottaviani G, Lavezzi AM, Grana DR, Stella I, Matturri L. Perinatal and infant early atherosclerotic coronary lesions. Can J Cardiol (2008) 24:137-41. doi:10.1016/S0828-282X(08)70570-1

4. Burgner DP, Cooper MN, Moore HC, Stanley FJ, Thompson PL, de Klerk NH, et al. Childhood hospitalisation with infection and cardiovascular disease explanation is the widespread introduction of antibiotics and vaccines in the post second world war years.

While food and nutrition are important influences on atherosclerosis, there is mounting evidence that infectious pathogens may initiate atherosclerosis. These influences commence in infancy and childhood, and atherosclerosis can be well established in some children as young as 12 years of age and in otherwise fit young adults. Many pathogens influence lipid metabolism, for example Marek's herpes virus, can cause atherosclerosis in experimental chickens in the absence of atherogenic diets. Multiple pathogens can infect both the normal and atherosclerotic vascular system, including the aorta and coronary arteries, having adverse influences on the endothelial lining and smooth muscle cells of blood vessel walls leading to inflammation.

There is evidence, which is not conclusive, that the herpes viruses, Cp, P. gingivalis, and Enterobacter coli may be the most influential pathogens associated with atherosclerosis.

The search for the causes of ACAD has been dominated by research into the influence of food and nutrition. It is timely to redirect research efforts.

\section{RECOGNITION}

The young soldiers killed in World War 1, Korea, Vietnam, Iraq, and Afghanistan are not just data and statistics. Necessarily, in this review, they are anonymous but not unknown. Sadly, they are sons, daughters, brothers, and sisters, and some are husbands and wives.

\section{AUTHOR CONTRIBUTIONS}

The author confirms being the sole contributor of this work and approved it for publication.

\section{ACKNOWLEDGMENTS}

The German to English translation of the 1915 Monckeberg article was by Tilmann Schneider of Sydney and Berlin. Wendy Glenn and Johan Duflou of Sydney, Jack Hirsh of Canada, Bryant Webber and Cynthia Leibson of the US gave comments and advice regarding the manuscript.

\section{SUPPLEMENTARY MATERIAL}

The Supplementary Material for this article can be found online at http://journal.frontiersin.org/article/10.3389/fcvm.2016.00030

in early-mid adulthood: a longitudinal population-based study. PLoS One (2015) 10:e0125342. doi:10.1371/journal.pone.0125342

5. Burgner DP, Sabin MA, Magnussen CG, Cheung M, Kähönen M, Lehtimäki $\mathrm{T}$, et al. Infection-related hospitalization in childhood and adult metabolic outcomes. Pediatrics (2015) 136:e554-62. doi:10.1542/peds.2015-0825

6. Velican D, Velican C. Study of fibrous plaques occurring in the coronary arteries of children. Atherosclerosis (1979) 33:201-5. doi:10.1016/0021-9150 (79)90117-5

7. Nguyen MU, Wallace MJ, Pepe S, Menheniott TR, Moss TJ, Burgner D. Perinatal inflammation: a common factor in the early origins of cardiovascular disease? Clin Sci (Lond) (2015) 129:769-84. doi:10.1042/ CS20150045 
8. Strong JP, Malcom GT, McMahan CA, Tracy RE, Newman WP III, Herderick EE, et al. Prevalence and extent of atherosclerosis in adolescents and young adults: implications for prevention from the pathobiological determinants of atherosclerosis in Youth Study. JAMA (1999) 281:727-35. doi:10.1001/ jama.281.8.727

9. Monckeberg JG. Anatomische veranderungen am kreislaufsystem bei kreigsteilnehmern. Zentralbl Herz Gefasskrankheiten (1915) 7:336-43.

10. Enos WF, Beyer JC, Holmes RH. Pathogenesis of coronary disease in American soldiers killed in Korea. JAMA (1955) 158:912-4. doi:10.1001/ jama.1955.02960110018005

11. McNamara JJ, Molot MA, Stremple JF, Cutting RT. Coronary artery disease in combat casualties in Vietnam. JAMA (1971) 216:1185-7. doi:10.1001/ jama.216.7.1185

12. Webber BJ, Seguin PG, Burnett DG, Clark LL, Otto JL. Prevalence of and risk factors for autopsy-determined atherosclerosis among US service members, 2001-2011. JAMA (2012) 308:2577-83. doi:10.1001/jama.2012.70830

13. Lawson JS, Glenn WK, Tran DD, Ngan CC, Duflou JA, Whitaker NJ. Identification of human papilloma viruses in atheromatous coronary artery disease. Front Cardiovasc Med (2015) 2:17. doi:10.3389/fcvm. 2015.00017

14. National Heart, Lung and Blood Institute (NHLBI). Disease Statistics in NHLBI Fact Book. Bethesda: National Institutes of Health (2014).

15. Nemetz PN, Smith CY, Bailey KR, Roger VL, Edwards WD, Leibson CL. Trends in coronary atherosclerosis: a tale of two population subgroups. Am J Med (2016) 129:307-14. doi:10.1016/j.amjmed.2015.10.032

16. Vital Statistics of the United States, National Center for Health Statistics. Health, United States. Hyattsville, MD (2014).

17. Booze CF, Staggs CM. A comparison of post-mortem atherosclerosis findings in general aviation plot fatalities. Aviat Space Environ Med (1987) 58:297-300.

18. Roger VL, Weston SA, Killian JM, Pfeifer EA, Belau PG, Kottke TE, et al. Time trends in the prevalence of atherosclerosis: a population-based autopsy study. Am J Med (2001) 110:267-73. doi:10.1016/S0002-9343(00)00709-9

19. Newman WP, Guzman MA, Strong JP, Tracy RE, Oalmann MC. Secular trends in atherosclerotic lesions: comparison of two studies of autopsied men conducted in different time periods. Mod Pathol (1988) 1:109-13.

20. Nemetz PN, Roger VL, Ransom JE, Bailey KR, Edwards WD, Leibson CL. Recent trends in the prevalence of coronary disease: a population-based autopsy study of nonnatural deaths. Arch Intern Med (2008) 168:264-70. doi:10.1001/archinternmed.2007.79

21. Mirzaei M, Truswell AS, Taylor R, Leeder SR. Coronary heart disease epidemics: not all the same. Heart (2009) 95:740-6. doi:10.1136/hrt.2008.154856

22. Kannel WB, Schwartz MJ, McNamara PM. Blood pressure and risk of coronary heart disease: the Framingham study. Dis Chest (1969) 56:43-52. doi:10.1378/chest.56.1.43

23. Yatsuya H, Li Y, Hilawe EH, Ota A, Wang C, Chiang C, et al. Global trend in overweight and obesity and its association with cardiovascular disease incidence. Circ J (2014) 78:2807-18. doi:10.1253/circj.CJ-14-0850

24. Fabricant CG, Fabricant J, Litrenta MM, Minick CR. Virus-induced atherosclerosis. J Exp Med (1978) 148:335-40. doi:10.1084/jem.148.1.335

25. Fabricant CG, Hajjar DP, Minick CR, Fabricant J. Herpesvirus infection enhances cholesterol and cholesteryl ester accumulation in cultured arterial smooth muscle cells. Am J Pathol (1981) 105:176-84.

26. Fabricant CG, Fabricant J. Atherosclerosis induced by infection with Marek's disease herpesvirus in chickens. Am Heart J (1999) 138(5 Pt 2):S465-8. doi:10.1016/S0002-8703(99)70276-0

27. Ibrahim AI, Obeid MT, Jouma MJ, Moasis GA, Al-Richane WL, Kindermann I, et al. Detection of herpes simplex virus, cytomegalovirus and Epstein-Barr virus DNA in atherosclerotic plaques and in unaffected bypass grafts. J Clin Virol (2005) 32:29-32. doi:10.1016/j.jcv.2004.06.010

28. Reszka E, Jegier B, Wasowicz W, Lelonek M, Banach M, Jaszewski R. Detection of infectious agents by polymerase chain reaction in human aortic wall. Cardiovasc Pathol (2008) 17:297-302. doi:10.1016/j.carpath.2007.11.002

29. Hsu HY, Nicholson AC, Pomerantz KB, Kaner RJ, Hajjar DP. Altered cholesterol trafficking in herpesvirus-infected arterial cells. Evidence for viral protein kinase-mediated cholesterol accumulation. J Biol Chem (1995) 270:19630-7. doi:10.1074/jbc.270.33.19630

30. Apostolou F, Gazi IF, Lagos K, Tellis CC, Tselepis AD, Liberopoulos EN, et al. Acute infection with Epstein-Barr virus is associated with atherogenic lipid changes. Atherosclerosis (2010) 212:607-13. doi:10.1016/j.atherosclerosis. 2010.06.006

31. Gargouri B, Nasr R, Mseddi M, Benmansour R, Lassoued S. Induction of Epstein-Barr virus (EBV) lytic cycle in vitro causes lipid peroxidation, protein oxidation and DNA damage in lymphoblastoid B cell lines. Lipids Health Dis (2011) 10:111. doi:10.1186/1476-511X-10-111

32. Fan J, Zhang W, Liu Q. Human cytomegalovirus-encoded miR-US25-1 aggravates the oxidised low density lipoprotein-induced apoptosis of endothelial cells. Biomed Res Int (2014) 2014:531979. doi:10.1155/2014/531979

33. Armingohar Z, Jørgensen JJ, Kristoffersen AK, Abesha-Belay E, Olsen I. Bacteria and bacterial DNA in atherosclerotic plaque and aneurysmal wall biopsies from patients with and without periodontitis. JOral Microbiol (2014) 6. doi:10.3402/jom.v6.23408

34. Mitra S, Drautz-Moses DI, Alhede M, Maw MT, Liu Y, Purbojati RW, et al. In silico analyses of metagenomes from human atherosclerotic plaque samples. Microbiome (2015) 3:38. doi:10.1186/s40168-015-0100-y

35. Popović M, Smiljanić K, Dobutović B, Syrovets T, Simmet T, Isenović ER. Human cytomegalovirus infection and atherothrombosis. J Thromb Thrombolysis (2012) 33:160-72. doi:10.1007/s11239-011-0662-x

36. Post WS, Budoff M, Kingsley L, Palella FJ Jr, Witt MD, Li X, et al. Associations between HIV infection and subclinical coronary atherosclerosis. Ann Intern Med (2014) 160:458-67. doi:10.7326/M13-1754

37. Mahendra J, Mahendra L, Nagarajan A, Mathew K. Prevalence of eight putative periodontal pathogens in atherosclerotic plaque of coronary artery disease patients and comparing them with noncardiac subjects: a case-control study. Indian J Dent Res (2015) 26:189-95. doi:10.4103/0970-9290.159164

38. Kuo HK, Fujise K. Human papillomavirus and cardiovascular disease among U.S. women in the National Health and Nutrition Examination Survey, 2003 to 2006. J Am Coll Cardiol (2011) 58:2001-6. doi:10.1016/j.jacc.2011.07.038

39. Bonin LR, Madden K, Shera K, Ihle J, Matthews C, Aziz S, et al. Generation and characterization of human smooth muscle cell lines derived from atherosclerotic plaque. Arterioscler Thromb Vasc Biol (1999) 19:575-87. doi:10.1161/01.ATV.19.3.575

40. Pigarevskii PV, Mal'tseva SV, Snegova VA, Davydova NG, Guseva VA. Chlamydia pneumoniae and immunoinflammatory reactions in an unstable atherosclerotic plaque in humans. Bull Exp Biol Med (2015) 159(2):278-81. doi:10.1007/s10517-015-2941-6

41. Sakurai-Komada N, Iso H, Koike KA, Ikeda A, Umesawa M, Ikehara S, et al. Association between Chlamydophila pneumoniae infection and risk of coronary heart disease for Japanese: the JPHC study. Atherosclerosis (2014) 233:338-42. doi:10.1016/j.atherosclerosis.2014.01.023

42. Sorrentino R, Yilmaz A, Schubert K, Crother TR, Pinto A, Shimada K, et al. A single infection with Chlamydia pneumoniae is sufficient to exacerbate atherosclerosis in ApoE deficient mice. Cell Immunol (2015) 294:25-32. doi:10.1016/j.cellimm.2015.01.007

43. Kwon TW, Kim DK, Ye JS, Lee WJ, Moon MS, Joo CH, et al. Detection of enterovirus, cytomegalovirus, and Chlamydia pneumoniae in atheromas. J Microbiol (2004) 42(4):299-304.

44. Kimura H. Pathogenesis of chronic active Epstein-Barr virus infection: is this an infectious disease, lymphoproliferative disorder, or immunodeficiency? Rev Med Virol (2006) 16:251-61. doi:10.1002/rmv.505

45. Serino M, Blasco-Baque V, Nicolas S, Burcelin R. Far from the eyes, close to the heart: dysbiosis of gut microbiota and cardiovascular consequences. Curr Cardiol Rep (2014) 16:540. doi:10.1007/s11886-014-0540-1

46. Koren O, Spor A, Felin J, Fak F, Stombaugh J, Tremaroli V, et al. Human oral, gut, and plaque microbiota in patients with atherosclerosis. Proc Natl Acad Sci U S A (2011) 108(Suppl):45924598. doi:10.1073/pnas.1011383107

47. Jandhyala SM, Talukdar R, Subramanyam C, Vuyyuru H, Sasikala M, Nageshwar Reddy D. Role of the normal gut microbiota. World J Gastroenterol (2015) 21:8787-803. doi:10.3748/wjg.v21.i29.8787

48. Azad MB, Konya T, Persaud RR, Guttman DS, Chari RS, Field CJ, et al. Impact of maternal intrapartum antibiotics, method of birth and breastfeeding on gut microbiota during the first year of life: a prospective cohort study. BJOG (2016) 123:983-93. doi:10.1111/1471-0528.13601

49. Berkhout B. With a little help from my enteric microbial friends. Front Med (2015) 2:30. doi:10.3389/fmed.2015.00030

50. Marmot MG, Syme SL. Acculturation and coronary heart disease in JapaneseAmericans. Am J Epidemiol (1976) 104:225-47. 
51. Truett J, Cornfield J, Kannel W. A multivariate analysis of the risk of coronary heart disease in Framingham. JChronic Dis (1967) 20:511-24. doi:10.1016/0021-9681(67)90082-3

52. Keys A, editor. Coronary heart disease in 7 countries. Circulation (1970) 41(Suppl):1-198.

53. Dawber DA, Kannel WB, Revotskie N, Kagan A. The epidemiology of coronary heart disease - the Framingham enquiry. Proc R Soc Med (1962) 55:265-71.

54. Sharpe LJ, Cook EC, Zelcer N, Brown AJ. The UPS and downs of cholesterol homeostasis. Trends Biochem Sci (2014) 39:527-35. doi:10.1016/j. tibs.2014.08.008

55. Chowdhury R, Warnakula S, Kunutsor S, Crowe F, Ward HA, Johnson L, et al. Association of dietary, circulating, and supplement fatty acids with coronary risk: a systematic review and meta-analysis. Ann Intern Med (2014) 160:398-406. doi:10.7326/M13-1788

56. Astrup A. A changing view on saturated fatty acids and dairy: from enemy to friend. Am J Clin Nutr (2014) 100:1407-8. doi:10.3945/ajcn.114.099986

57. de Souza RJ, Mente A, Maroleanu A, Cozma AI, Ha V, Kishibe T, et al. Intake of saturated and trans unsaturated fatty acids and risk of all cause mortality, cardiovascular disease, and type 2 diabetes: systematic review and meta-analysis of observational studies. BMJ (2015) 351:h3978. doi:10.1136/ bmj.h3978

58. Berger S, Raman G, Vishwanathan R, Jacques PF, Johnson EJ. Dietary cholesterol and cardiovascular disease: a systematic review and meta-analysis. Am J Clin Nutr (2015) 102:276-94. doi:10.3945/ajcn.114.100305

59. Hooper L, Martin N, Abdelhamid A, Davey Smith G. Reduction in saturated fat intake for cardiovascular disease. Cochrane Database Syst Rev (2015) (6):CD011737. doi:10.1002/14651858.CD011737

60. Twig G, Yaniv G, Levine H, Leiba A, Goldberger N, Derazne E, et al. Bodymass index in 2.3 million adolescents and cardiovascular death in adulthood. N Engl J Med (2016) 374:2430-40. doi:10.1056/NEJMoa1503840

61. FAO Statistics. Food Consumption Tables and Food Balance Sheets. Rome: Food and Agriculture Organisation of the United Nations (1954-2015).

62. World Health Organization. World Health Statistics Annuals 1995. Geneva (2015).

63. Marmot MG, Syme SL, Kagan A, Kato H, Cohen JB, Belsky J. Epidemiologic studies of coronary heart disease and stroke in Japanese men living in Japan, Hawaii and California: prevalence of coronary and hypertensive heart disease and associated risk factors. Am J Epidemiol (1975) 102: $514-25$.

64. Choudhury SR. Curb5 for the INTERLIPID Research Group differences in cardiovascular disease risk factors between Japanese in Japan and JapaneseAmericans in Hawaii: the INTERLIPID study. J Hum Hypertens (2003) 17:631-9. doi:10.1038/sj.jhh.1001606

65. Epstein SE, Zhu J, Najafi AH, Burnett MS. Insights into the role of infection in atherogenesis and in plaque rupture. Circulation (2009) 119:3133-41. doi:10.1161/CIRCULATIONAHA.109.849455

66. Campbell LA, Rosenfeld ME. Infection and atherosclerosis development. Arch Med Res (2015) 46:339-50. doi:10.1016/j.arcmed.2015.05.006

67. Feingold KR, Grunfeld C. The Effect of Inflammation and Infection on Lipids and Lipoproteins. ENDOTEXT. South Dartmouth, MA: MDText.com, Inc. (2000-2015).

68. Clifford A, Hoffman GS. Evidence for a vascular microbiome and its role in vessel health and disease. Curr Opin Rheumatol (2015) 27:397-405. doi:10.1097/BOR.0000000000000184

69. Speir E, Modali R, Huang ES, Leon MB, Shawl F, Finkel T, et al. Potential role of human cytomegalovirus and p53 interaction in coronary restenosis. Science (1994) 265:391-4. doi:10.1126/science. 8023160

70. Fan T, Lu H, Hu H, Shi L, McClarty GA, Nance DM, et al. Inhibition of apoptosis in chlamydia-infected cells: blockade of mitochondrial cytochrome c release and caspase activation. J Exp Med (1998) 187:487-96. doi:10.1084/ jem.187.4.487

71. Zhou YF, Guetta E, Yu ZX, Finkel T, Epstein SE. Human cytomegalovirus increases modified low density lipoprotein uptake and scavenger receptor mRNA expression in vascular smooth muscle cells. JClin Invest (1996) 98:2129-38. doi:10.1172/JCI119019

72. Brodala N, Merricks EP, Bellinger DA, Damrongsri D, Offenbacher S, Beck J, et al. Porphyromonas gingivalis bacteremia induces coronary and aortic atherosclerosis in normocholesterolemic and hypercholesterolemic pigs. Arterioscler Thromb Vasc Biol (2005) 25:1446-51. doi:10.1161/01. ATV.0000167525.69400.9c

73. Turkay C, Saba R, Sahin N, Altunbas H, Ozbudak O, Akkaya B, et al. Effect of chronic Pseudomonas aeruginosa infection on the development of atherosclerosis in a rat model. Clin Microbiol Infect (2004) 10:705-8. doi:10.1111/j.1469-0691.2004.01048.x

74. Gurven M, Kaplan H, Winking J, Eid Rodriguez D, Vasunilashorn S, Kim JK, et al. Inflammation and infection do not promote arterial aging and cardiovascular disease risk factors among lean horticulturalists. PLoS One (2009) 4:e6590. doi:10.1371/journal.pone.0006590

75. Vasunilashorn S, Crimmins EM, Kim JK, Winking J, Gurven M, Kaplan H, et al. Blood lipids, infection, and inflammatory markers in the Tsimane of Bolivia. Am J Hum Biol (2010) 22:731-40. doi:10.1002/ajhb.21074

76. Low H, Cheng L, Di Yacovo MS, Churchill MJ, Meikle P, Bukrinsky M, et al. Lipid metabolism in patients infected with Nef-deficient HIV-1 strain. Atherosclerosis (2016) 244:22-8. doi:10.1016/j.atherosclerosis.2015. 10.103

77. Sun $\mathrm{S}$, Cheng B, Wu X, Wu Q, Qi B, Wu J, et al. Chlamydia pneumoniae disrupts lipid metabolism in human umbilical vein endothelial cells. Mol Med Rep (2014) 10:1150-6. doi:10.3892/mmr.2014.2295

78. Bobryshev YV, Killingsworth MC, Tran D, Lord R. Amalgamation of Chlamydia pneumoniae inclusions with lipid droplets in foam cells in human atherosclerotic plaque. Virchows Arch (2008) 453:69-77. doi:10.1007/ s00428-008-0629-2

79. Stehr M, Elamin AA, Singh M. Cytosolic lipid inclusions formed during infection by viral and bacterial pathogens. Microbes Infect (2012) 14:1227-37. doi:10.1016/j.micinf.2012.08.001

80. Marangoni A, Fiorino E, Gilardi F, Aldini R, Scotti E, Nardini P, et al. Chlamydia pneumoniae acute liver infection affects hepatic cholesterol and triglyceride metabolism in mice. Atherosclerosis (2015) 241:471-9. doi:10.1016/j.atherosclerosis.2015.05.023

81. Chen S, Shimada K, Zhang W, Huang G, Crother TR, Arditi M. IL-17A is proatherogenic in high-fat diet-induced and Chlamydia pneumoniae infection-accelerated atherosclerosis in mice. J Immunol (2010) 185:5619-27. doi:10.4049/jimmunol.1001879

82. Maekawa T, Takahashi N, Tabeta K, Aoki Y, Miyashita H, Miyauchi S, et al. Chronic oral infection with Porphyromonas gingivalis accelerates atheroma formation by shifting the lipid profile. PLoS One (2011) 6:e20240. doi:10.1371/ journal.pone. 0020240

83. Li XY, Wang C, Xiang XR, Chen FC, Yang CM, Wu J. Porphyromonas gingivalis lipopolysaccharide increases lipid accumulation by affecting CD36 and ATP-binding cassette transporter A1 in macrophages. Oncol Rep (2013) 30:1329-36. doi:10.3892/or.2013.2600

84. Kempe S, Heinz P, Kokai E, Devergne O, Marx N, Wirth T. Epstein-Barr virus-induced gene-3 is expressed in human atheroma plaques. Am J Pathol (2009) 175:440-7. doi:10.2353/ajpath.2009.080752

85. Syed GH, Amako Y, Siddiqui A. Hepatitis C virus hijacks host lipid metabolism. Trends Endocrinol Metab (2010) 21:33-40. doi:10.1016/j. tem.2009.07.005

86. Sanchez V, Dong JJ. Alteration of lipid metabolism in cells infected with human cytomegalovirus. Virology (2010) 404:71-7. doi:10.1016/j.virol.2010. 04.026

87. Machesky NJ, Zhang G, Raghavan B, Zimmerman P, Kelly SL, Merrill AH Jr, et al. Human cytomegalovirus regulates bioactive sphingolipids. J Biol Chem (2008) 283:26148-60. doi:10.1074/jbc.M710181200

88. Huang B, Chen Y, Xie Q, Lin G, Wu Y, Feng Y, et al. CagA-positive Helicobacter pylori strains enhanced coronary atherosclerosis by increasing serum OxLDL and HsCRP in patients with coronary heart disease. Dig Dis Sci (2011) 56:109-14. doi:10.1007/s10620-010-1274-6

89. Louw L, Seedat R, Claassen A. HPV-induced recurrent laryngeal papillomatosis: fatty acid role-players. Asia Pac J Clin Nutr (2008) 17(Suppl 1):208-11.

90. Kelesidis T, Currier JS. Dyslipidemia and cardiovascular risk in human immunodeficiency virus infection. Endocrinol Metab Clin North Am (2014) 43:665-84. doi:10.1016/j.ecl.2014.06.003

91. Popper K. The Logic of Scientific Discovery. London, UK: Routledge Classics (2002).

92. Ford ES, Ajani UA, Croft JB, Critchley JA, Labarthe DR, Kottke TE, et al. Explaining the decrease in U.S. deaths from coronary disease, 1980-2000. N Engl J Med (2007) 356:2388-98. doi:10.1056/NEJMsa053935 
93. A report of the Surgeon General. The Health Consequences of Smoking: 50 Years of Progress. Rockville: US Department of Health and Human Services (2014).

94. Messner B, Bernhard D. Smoking and cardiovascular disease: mechanisms of endothelial dysfunction and early atherogenesis. Arterioscler Thromb Vasc Biol (2014) 34:509-15. doi:10.1161/ATVBAHA.113.300156

95. Egan BM, Zhao Y, Axon RN. US trends in prevalence, awareness, treatment, and control of hypertension, 1988-2008. JAMA (2010) 303:2043. doi:10.1001/ jama.2010.650

96. Gao WQ, Feng QZ, Li YF, Li YX, Huang Y, Chen YM, et al. Systematic study of the effects of lowering low-density lipoprotein-cholesterol on regression of coronary atherosclerotic plaques using intravascular ultrasound. BMC Cardiovasc Disord (2014) 14:60. doi:10.1186/1471-226114-60

97. Madan M, Bishayi B, Hoge M, Messas E, Amar S. Doxycycline affects dietand bacteria-associated atherosclerosis in an ApoE heterozygote murine model: cytokine profiling implications. Atherosclerosis (2007) 190:62-72. doi:10.1016/j.atherosclerosis.2006.02.026

98. Membrez M, Blancher F, Jaquet M, Bibiloni R, Cani PD, Burcelin RG, et al. Gut microbiota modulation with norfloxacin and ampicillin enhances glucose tolerance in mice. FASEB J (2008) 22:2416-26. doi:10.1096/f.07102723

99. Cotter PD, Stanton C, Ross RP, Hill C. The impact of antibiotics on the gut microbiota as revealed by high throughput DNA sequencing. Discov Med (2012) 13:193-9.

100. Tulstrup MV, Christensen EG, Carvalho V, Linninge C, Ahrné S, Højberg O, et al. Antibiotic treatment affects intestinal permeability and gut microbial composition in Wistar rats dependent on antibiotic class. PLoS One (2015) 10:e0144854. doi:10.1371/journal.pone.0144854

Conflict of Interest Statement: The author declares that the research was conducted in the absence of any commercial or financial relationships that could be construed as a potential conflict of interest.

Copyright $\odot 2016$ Lawson. This is an open-access article distributed under the terms of the Creative Commons Attribution License (CC BY). The use, distribution or reproduction in other forums is permitted, provided the original author(s) or licensor are credited and that the original publication in this journal is cited, in accordance with accepted academic practice. No use, distribution or reproduction is permitted which does not comply with these terms. 